\title{
Building Local Communities: Place-Shaping as Nation-Building
}

\author{
STEVEN VAN DE WALLE
}

\begin{abstract}
The Lyons Inquiry into Local Government has introduced the English local government community to the concept of 'placeshaping'. Place-shaping refers to the new role for local governments in promoting the well-being of communities and citizens. The processes of place-shaping are remarkably similar to the processes of nationbuilding. This paper uses Stein Rokkan's thinking on nation-building in Western Europe to analyse place-shaping. It focuses on the penetration and standardisation processes and underlines the importance of integrating peripheries, defining boundaries, and creating identities. In essence, it is argued that place-shaping is really about the repolitisation of English local authorities.
\end{abstract}

KEYWORDS: • nation-building $\bullet$ local identity $\bullet$ community building place-shaping $\bullet$ English local government

Correspondence Address: Steven Van de Walle, Ph.D., Department of Public Administration, Faculty of Social Scienes, Erasmus University Rotterdam, P.O. Box 1738, 3000 DR Rotterdam, The Netherlands, e-mail: vandewalle@fsw.eur.nl. 
Place-shaping has become one of the key concepts in the extremely vivid discussion on the English local government reform. It was introduced to the debate through the Lyons Inquiry into Local Government, last but not least through its 2007 final report 'Place Shaping: A Shared Ambition for the Future of Local Government', and lingers prominently in much of the current debates on local governance and the trends towards outcome-based central-local steering mechanisms. Place-shaping basically means that local authorities should employ strategic leadership to promote the well-being of a local community and its citizens. This well-being should not be approached from just an economic or service delivery perspective, but it should also contain an element of a local sense of belonging and identity.

In this paper, we approach 'place-shaping' using Stein Rokkan's classic work on nation- building (see e.g. Eisenstadt \& Rokkan, 1973; Flora, Kuhnle, \& Urwin, 1999; Rokkan, Urwin, Aarebrot, Malaba, \& Sande, 1987). We argue that those factors, which have influenced $19^{\text {th }}$ century nation-building in most of Western Europe, as well as later in many developing countries after decolonisation, are also relevant to analysing the community-building and place-shaping processes at the local level. Different factors and processes related to the daily functioning of governments and states may contribute to the creation of a nation. Likewise, place-shaping occurs through a deliberate or unconscious series of government and community acts.

We first describe the concept of place-shaping as it is used in the Lyons inquiry. Then we briefly present Rokkan's thinking on nation-building. After looking into the nation-building processes, we show how they may contribute to creating local identity and to efficient shaping a place. We conclude our paper by giving a number of critical notes highlighting possible problems with the concept and process of place-shaping.

\section{$2 \quad$ What is Place-Shaping?}

Place-shaping is a rather broad term with different but related meanings. Placemaking has been used as an alternative term (Local Government Association, 2006: 21). The concept has gained prominence as a result of its use in the Lyons Inquiry into Local Government, and the Inquiry's publications are therefore the canonical source of place shaping information. There we find different but related definitions and descriptions of the concept.

The 2006 interim report 'National Prosperity, Local Choice and Civic Engagement' describes place-shaping as 
'influencing local well-being through providing high quality and responsive services, building strong communities and planning for the future.' (Lyons, 2006: 35)

The 2007 final report of the Inquiry titled 'Place-shaping: A Shared Ambition for the Future of Local Government' puts forward a number of related definitions. We start with the most common one:

'The modern role of local government can be described as 'place-shaping' - the creative use of powers and influence to promote the general wellbeing of a community and its citizens.' (Lyons, 2007b: 51)

Two other definitions are somewhat longer:

'The concept of place-shaping underlines the importance of communities taking responsibility for their own economic fortunes, and for striking the right balance between economic, environmental and social objectives and concerns.' (Lyons, 2007b: 13)

'The term place-shaping covers a wide range of local activity - indeed anything which affects the well-being of the local community. It will mean different things in different places and at different levels of local government, informed by local character and history, community needs and demands, and local politics and leadership.'(Lyons, 2007b: 174)

The glossary of the final report defines place-shaping as

'The creative use of powers and influence to promote the general wellbeing of a community and its citizens.' (Lyons, 2007b: 393)

The 2006 Local Government White Paper saw place-shaping as a role for local authorities, agencies and other groups 'to develop a vision for their area and work to make it happen imaginatively and jointly.' (Department for Communities and Local Government, 2006: 11)

But what does place-shaping actually mean? Again, we can refer to the final report of the Lyons Inquiry. It lists the following components of place-shaping (Lyons, 2007b: 3):

- 'building and shaping local identity;

- representing the community;

- regulating harmful and disruptive behaviours;

- maintaining the cohesiveness of the community and supporting debate within it, ensuring smaller voices are heard;

- helping to resolve disagreements;

- working to make the local economy more successful while being sensitive to pressures on the environment;

- $\quad$ understanding local needs and preferences and making sure that the right services are provided to local people; and 
- working with other bodies to respond to complex challenges such as natural disasters and other emergencies.'

A series of examples of place-shaping and local strategic leadership in related documents further helped to create a common understanding of the concept (Entwistle et al., 2007; Leadership Centre for Local Government, 2007).

Place-shaping should certainly be seen as broader than just regeneration (Lyons, 2007b: 61), and Lyons uses the concept in relation to many issues: planning, housing, skills development, transport, adult social care, domestic waste, community safety, health and well-being, and children's services. In documents, and in a wider debate on place-shaping, a number of elements constantly return, and these elements summarise the meaning of place-shaping:

Local choice. Local communities are best placed to decide on local services and development. Rather than relying on national indicators, we should recognise local people as 'the ultimate judges of the performance of their local authorities' (Lyons, 2007b: 8).

Identity. A central feature of place-shaping is that it approaches local government 'as about more than delivering or commissioning services' (Local Government Association, 2006: 21). Place-shaping has to do with building cohesive communities (Department for Communities and Local Government, 2006: 94). While Lyons recognises that place has lost its importance as the main determinant of personal identity (Lyons, 2007b: 55), he does emphasise that local structures should reflect citizens' sense of place. He therefore highlights issues such as social engagement and social capital (Lyons, 2007b: 65-6), and community identity and pride in place (Lyons, 2007b: 66) as key elements of place-shaping. Placeshaping, in short, is 'about creating a vision for a locality that is distinctive, identifying and building on its unique selling points, and creating a sense of local identity, distinctiveness and place. It is about creating places that are attractive, vibrant, prosperous, safe and friendly. Places for people to be proud to call home' (Local Government Association, 2006: 21).

Strategic leadership. Place-shaping requires strategic leadership, a role that local government has ceded or has had to cede to central government. The White Paper describes local government, not central government, as the main 'strategic leader and place-shaper'(Department for Communities and Local Government, 2006: 10). Local authorities again have to take initiative and responsibility. This requires a view 'beyond the immediate delivery of services, the short-term electoral cycle and the timetables of funding and performance management' (Lyons, 2007a: 16), and it is all about vision. Strategic leadership is political leadership (Lyons, 2007b: 179). It involves 'the setting of clear priorities and making difficult choices, resolving conflict and balancing different demands and views' (Lyons, 2007b: 177), and as such entails arbitration and persuasion. 
Integrated approaches. Implementing a vision for a local area requires integrated approaches and joining resources (Local Government Association, 2006: 13). Leadership includes the ability to interact with a wide range of actors and to induce these actors to work together to form an integrated local network. Placeshaping also reflects an integrated approach to an area, as opposed to silo-based service delivery (Lyons, 2007b: 5) in order to tackle a wide range of problems ranging from regeneration, over demographic transformation to climate change.

A recurrent theme throughout the discussion is the desire to give local authorities back the responsibility and means to make a difference at the local level after decades of overcentralisation. Local authorities 'need to develop a new confidence and a new sense of powerfulness' (Lyons, 2007b: 44). For this reason, some have commented that 'leadership of place is nothing new, it is actually a return to the historic role of local government' (Leadership Centre for Local Government, 2007: 1).

\section{Lessons from the Nation-Building Literature}

Place-shaping at the local level is still in its infancy and is struggling with criticism about the vagueness of the concept. The current debates on placeshaping, local governance, reconnecting with citizens, and on curing divided societies echo the academic debate on nation-building. The nation-building literature focuses on how, within a certain territory, states have shaped nations by producing certain policies, artefacts, and symbols. Nation-building has frequently been defined as 'community-building' where disparate population elements had to be welded into a congruent whole (Kolsto, 1999; Deutsch, 1963). This was done by forging new identities at the expense of particularistic identifications (Kolsto, 1999). It is from this perspective that we wish to analyse the place-shaping debate. In doing so, we will make extensive use of the work of the late Stein Rokkan, the 'godfather' of the state- and nation-building theory.

\section{State- and Nation-Building}

Traditionally, the nation-building literature has focused on nation-building processes in Western European States, and theorising was in its heyday in the 1960s-70s (Martinez-Herrera, 2002: 422; Tilly, 1975a; Bendix, 1964; Eisenstadt \& Rokkan, 1973). This is the period in which we find many models and theories that are still in use today. This literature focused first on state building in the $17^{\text {th }}$ and $18^{\text {th }}$ centuries, emphasising the birth of modern states, and subsequently moved on to studying the nation-building processes in the $19^{\text {th }}$ century. More recent waves of nationalism in Europe, as for instance expressed in regionalist movements in some regions such as Flanders, Catalonia, or Scotland, have been accompanied by the renewed attention to nation-building. Nation-building or rather state building has also received considerable attention in relation to the newly independent former colonies. Currently, nation-building is also very much 
en vogue in the international development community, and is now often used in the context of failed states (Fukuyama, 2004).

We first need to distinguish between two interrelated concepts: state-building and nation-building. Not all states are nations, and not all nations have states. State building has to do with structures, while nation-building has to do with communities. The state is likely to emerge or come into existence through a topdown or coercive mechanism, while building a nation may require more than topdown decisions and coercion. This does not mean, however, that coercive pressures are absent in nation-building. Generally, however, we could say that state building has historically often been a costly process for populations, especially during its early stages. On the other hand, nation-building has had a much more positive tone (Tilly, 1975b: 71).

\section{Developing a Political System}

In state- and nation-building, we are really talking about the development of a political system. Almond and Powell distinguish five main problems or stages of such development (Almond \& Powell, 1978: 22). The first one is state building where the system is faced with the problems of penetration and integration. The second one is nation-building where loyalty and commitment need to be created. The third one refers to the problem of participation where there is a popular demand for participation in decision making. The fourth one is economy building. And finally there is a challenge of redistribution or welfare. In a similar way, Rokkan distinguished four processes of creating loyalty within a certain geographic area, and thus, basically, shaping a place (Flora et al., 1999: 125). The first process is penetration associated with state building. It is often quite a coercive process. It is the process of establishing an internal order, solving major disputes, extracting resources, and last but not least, it is the process of political, economic, and cultural unification at the elite level. The second process is generally associated with nation-building, and can generally be located in Western European countries in the mid-to-late $19^{\text {th }}$ century. It is the process of standardisation within the territory, and this standardisation occurs through the creation of common channels of communication. These channels consist of transport links, the media, and a series of standardised public services such as schools, railway stations, town halls, etc. that make the state visible in every-day life. In the state-building phase, the state was still a coercive or even oppressive entity and relatively absent from everyday life for most people, nation-building sought to create a national identity. The third stage adds political citizenship that includes equalisation of participation rights. Finally, the fourth stage concentrates on the redistribution of resources and benefits, and on the creation of a social citizenship. It signals the gradual emergence of a welfare state.

\section{Integrating Centres and Peripheries}

The core distinction in the state- and nation-building literature is that between centres and peripheries. Centres can be defined as 'privileged locations within a 
territory where key military, administrative, economic, and cultural resourceholders most frequently meet with established arenas for deliberations, negotiations, and decision-making; where people convene for ritual ceremonies of affirmation of identity; with the largest proportion of economically active population engaged in the processing and communication of information and instructions over long distances' (Rokkan \& Urwin, 1982: 5). A periphery, by contrast, 'is dependent, controlling only its own resources at best, and it is more exposed to fluctuations in long-distance markets; it is isolated from all other regions, except for the central one; and it contributes little to the total flow of communication within the territory with the marginal culture that is fragmented and parochial, yet not fully dominant across the politically defined territory' (Rokkan \& Urwin, 1982: 5). Peripheries are not necessarily defined only in geographical terms (horizontal peripheries), but they may also refer to the groups of people who are remote from central decision-making, or otherwise disengaged (vertical peripheries). Peripheries are often dependent, and those who rule them are often more responsive to the centre than to the desires of the periphery (Flora et al., 1999: 113). Fragmented cities or localities have a similar centre-periphery distinction. The centre (or centres) holds the political, cultural and economic power, while the peripheries are territories or groups that do not hold these powers: estates, abandoned neighbourhoods, certain ethnic minorities, etc.

There is also another type of periphery. The periphery described above is one without power, without unified or distinctive culture. Other peripheries may in fact be potential competing centres, holding considerable political, economic and cultural power. Such a situation is not uncommon in local government where local authorities may consist of several previously independent units. In such a case, integrating peripheries may require federal or consociational strategies rather than standardisation and centralisation.

Centre and periphery connect through political, cultural, and economic transactions. 'Penetration' required for integrating peripheries can be done in different ways. Coercion, e.g., when the police bring certain neighbourhoods back under their control, is just one mechanism. Integration and penetration may also occur through economic means by investing money or by employment, through cultural means by establishing schools, churches or cultural facilities, and more generally by improving transactions between the centre and periphery, and between different peripheries.

\section{Defining and Building Boundaries}

The second important factor in nation-building, and thus also in place-shaping, is boundary building. Boundary building determines a geographical space and a membership space (Flora et al., 1999: 104). Boundaries determine who belongs and who does not. The current movement towards a unitary system in local government reflects a desire to have clear boundaries and confirms that placeshaping follows a similar logic as nation-building (yet we need to add that place- 
shaping is generally not the main argument for such changes). Creating such boundaries is relatively easy when the territory of a local authority is sufficiently distinct from the neighbouring authorities in economic and cultural terms. Often, however, especially in the peripheries, such a distinction is not always straightforward.

Boundaries may be defined in such a way as to exclude certain groups within the local territory. On the other hand, membership definitions may be very narrow and suffocating. There are clearly instances where boundaries are set so that the local community membership is not extended, e.g., to Eastern European labourers, members of certain religious or ethnic groups, or inhabitants of certain neighbourhoods.

People may have different identities along geographical, socio-economic, and cultural lines. Different sets of boundaries do not necessarily coincide. When this is the case, nation-building and place-shaping become considerably more difficult, especially when the local authority-defined boundary is clearly the weakest one. Low local social cohesion and an absence of local pride (Hunt, 2005) suggests this may actually be the case.

\section{Building Communities and Creating Loyalty}

When boundaries are disputed and peripheries are insufficiently integrated, the local level may be faced with the relevant problems of legitimacy, and there may exist a clear need for stimulating loyalty. This is where the creation of community and identity comes into play. Nationalism, the ideological component of nationbuilding, is about creating identity and loyalty. Such a process is also used at the local level. Political entities create identities through penetration and integration processes, and through the processes of standardisation and harmonisation. France's $19^{\text {th }}$ century efforts to turn peasants into Frenchmen (Weber, 1976) do not differ essentially from the current efforts at the local level to turn yobs, chavs, disengaged citizens, members of different religious and ethnic groups, different social classes, etc. into 'proper' Brummies, Liverpudlians or Mancunians. Increased attention to city branding also contributes to asserting this identity to the outside world (those beyond the established boundaries) (Koller, 2007). Hobsbawn described nationalism as a civic religion (Hobsbawm, 1972). Nationalism creates imagined communities (Anderson, 1983). Cities and municipalities build their own identities on a combination of facts and myths. A strong local identity depends on an idealised image of the city that can be used as a rallying point. When we called Birmingham, 'city of a thousand trades', or 'the workshop of the world', this reflected how the city was seen and wanted to be seen. $19^{\text {th }}$ century Manchester nicknamed 'Cottonopolis' and Glasgow nicknamed the 'Second City of the Empire' are other examples where such local identities expressed local civic pride. When Birmingham Tourist Information Centre compares (the length of) Birmingham's canals with the Venice canals, it wants to convey a certain message, not only externally, but also internally. City marketing 
and branding, while generally used for external purposes, may also have internal effects. Such an internal use is not all that different from nationalism. One element of the new localism is about the creation of local identity, pride, and a sense of belonging.

However, developing a sense of belonging and identity also implies disloyal behaviour restrictions. It may stimulate negative behaviour towards out-groups. In areas with disputed or incomplete boundary building, these processes of identity creation may lead to a conflict. As we have seen in the previous section, community building may deliberately exclude certain territories or population groups. Building communities may require a degree of undesirable cultural unification. The European nation-building practices differ in this respect. France, for instance, relied on a project of cultural unification, while countries such as Belgium or the Netherlands had to work in a more creative way with the existing cleavages in society (Lijphart, 1977).

Conflicting views about the 'shape of the place' may make effective place-shaping difficult. In the case of nation-building, elites were the motor of national identity. The focus on the leadership dimension suggests a similar practice in placeshaping. When this created identity remains an elite- or centre-focused exercise, it may contribute to fragmentation. In the case of city branding, Koller stressed that the attainment of 'brand uniformity' may be hard to maintain due to competing claims and understandings (Koller, 2007).

\section{$3 \quad$ Place-Shaping as Nationalism? An Evaluation}

By comparing place-shaping to nation-building, one could get the impression that we are talking about integrated macro-processes. Yet it is unclear to what extent a place can be shaped and a nation built in a deliberate way (Etzioni, 2004). Lyons' concept of place-shaping has been criticised for its extremely vague and general character. But place-shaping may simply not be the conscious, coherent and deliberate process we would like it to be for policy purposes. The communitybuilding processes are inherent in many local activities. We have already mentioned city-branding by tourist offices. Place-shaping may depend on an accumulation of little things: community commissioning, local recruitment, improving transport links between centre and periphery, winning football matches, the organisation of a festival, the worship of local heroes. The best examples of place-shaping processes can be found in the construction of public buildings, or in city centre regeneration. In his seminal epos about the Victorian city, Tristram Hunt mentioned the importance of the civic building, town halls, and squares as community symbols for these cities (Hunt, 2005).

The true message in the place-shaping debate is one of repoliticising local authorities rather than treating them as mere service delivery bodies. This does not come without dangers. The cultivation of local myths may blur the evidence-based 
policy. It may lead to budget spiralling and prestige projects with doubtful results. It may lead to unhealthy inter-city competition. It may lead to regional and social inequalities. This is something Lyons also recognised when he addressed the tension between recognising local distinctiveness and local choice, and assuring consistency in standards (Lyons, 2007b: iii).

Finally, there is a danger that we too exclusively focus on old models, such as nation-building, to describe or prescribe the current processes. The success of past processes is no guarantee for success in the present, despite the many similarities we have described. A particular difficulty lies in the apparent desire for local reforms to create unitary models with firm boundaries. Nation-building is a model that typically refers to the $19^{\text {th }}$ century processes of building nation states that are territory-based. It is not clear to what extent such a model is still relevant or even workable in a governance context. Other models, such as the medieval model consisting of territorially differentiated overlapping authorities, may be alternatives.

\section{Conclusion}

In this paper, we analysed the concept of place-shaping in the context of English local government, and the apparent parallels between this concept and the much older one of nation-building. We argued that 'shaping a place' is in essence remarkably similar to the processes of nation-building and nationalism in $19^{\text {th }}$ century Western Europe. Using Stein Rokkan's writings on state and nationbuilding, we compared place-shaping to the process of developing a new political system. Requirements for such a development are the integration of vertical and horizontal peripheries, the definition of boundaries, and the creation of a local identity and community. These processes also come with a number of dangers, and we need to be aware of these issues when taking the concept of place-shaping forward.

\section{References}

Almond, G. A., \& Powell, G. B. Jr. (1978) Comparative politics: Systems, process, and policy (2nd ed.). (Boston: Little, Brown and Company).

Anderson, B. (1983) Imagined communities: Reflections on the origins and spread of nationalism (New York: Verso).

Bendix, R. (1964) Nationbuilding and citizenship: Studies of our changing social order (New York: John Wiley \& Sons, Inc.).

Department for Communities and Local Government (2006) Strong and prosperous communities: The local government white paper (London: Department for Communities and Local Government).

Deutsch, K. W. (1963) Nation building and national development: Some issues for political research, In: Deutsch, K. W. \& Foltz, W. J. (eds.), Nationbuilding (New York: Atherton Press). 
Eisenstadt, S. N., \& Rokkan, S. (1973). Building states and nations: Models and data resources, Volume I. (London: Sage Publications).

Entwistle, T., Darlow, A., Downe, J., Dowson, L., Gains, F., John, P., Greasley, S., Sweeting, D., \& Turner, K. (2007) Perspectives on place-shaping and service delivery: A report of case study work conducted for the Lyons inquiry (Cardiff: Centre for Local and Regional Government Research, Cardiff University).

Etzioni, A. (2004) A self-restrained approach to nationbuilding by foreign powers, International Affairs, 80 (1), pp. 1-17.

Flora, P., Kuhnle, S., \& Urwin, D. (1999) State formation, nationbuilding, and mass politics in Europe: The theory of Stein Rokekan (Oxford: Oxford University Press).

Fukuyama, F. (2004) State building: governance and world order in the twenty-first century (London: Profile books).

Hobsbawm, E. (1972) Some reflections on nationalism, In: Nossiter, T. J. , Hanson, A. H. \& Rokkan, S. (eds.), Imagination and precision in the social sciences: Essays in memory of Peter Nettl (London: Faber).

Hunt, T. (2005) Building Jerusalem: the rise and fall of the Victorian city (London: Phoenix).

Koller, V. (2007) "The world in one city": semiotic and cognitive aspects of city branding, Paper presented at the CDA Symposium, Aston University/University of Birmingham, 7 July 2007.

Kolstø, P. (1999) Nationbuilding and social integration theory, In: Kolstø, P. (ed.), Nationbuilding and ethnic integration in post-Soviet societies: An investigation of Latvia and Kazakstan (Boulder, CO: Westview).

Leadership Centre for Local Government (2007) The politics of place (London: Leadership Centre for Local Government).

Lijphart, A. (1977) Democracy in plural societies (New Haven: Yale University Press).

Local Government Association (2006) Closer to people and places: A new vision for local government (London: Local Government Association).

Lyons, M. (2006) National prosperity, local choice and civic engagement: A new partnership between central and local government (London: Lyons Inquiry into Local Government).

Lyons, M. (2007a) Place-shaping: A shared ambition for the future of local government-executive summary (London: Lyons Inquiry into Local Government).

Lyons, M. (2007b) Place-shaping: A shared ambition for the future of local government - final report (London: Lyons Inquiry into Local Government).

Martinez-Herrera, E. (2002) From nation-building to building identification with political communities: Consequences of political decentralisation in Spain, the Basque country, Catalonia and Galicia, 1978-2001, European Journal of Political Research, 41 (4), pp. 421-453.

Rokkan, S., Urwin, D., Aarebrot, F. H., Malaba, P., \& Sande, T. (1987) Centre-periphery structures in Europe: An ISSC workbook in comparative analysis (Frankfurt: Campus Verlag).

Rokkan, S., \& Urwin, D. W. (1982) Introduction: Centres and peripheries in Western Europe, In: Rokkan, S. \& Urwin, D. W. (eds.), The politics of territorial identity: Studies in European regionalism (London: Sage), pp. 1-17.

Tilly, C. (1975a) The formation of national states in Western Europe (Princeton, New Jersey: Princeton University Press).

Tilly, C. (1975b) Reflections on the history of European state-making, In: Tilly, C. (ed.), The formation of national states in Western Europe (Princeton, New Jersey: Princeton University Press), pp. 3-83.

Weber, E. (1976) Peasants into Frenchmen: The modernization of rural France, 1870-1914 (Stanford: Stanford University Press). 